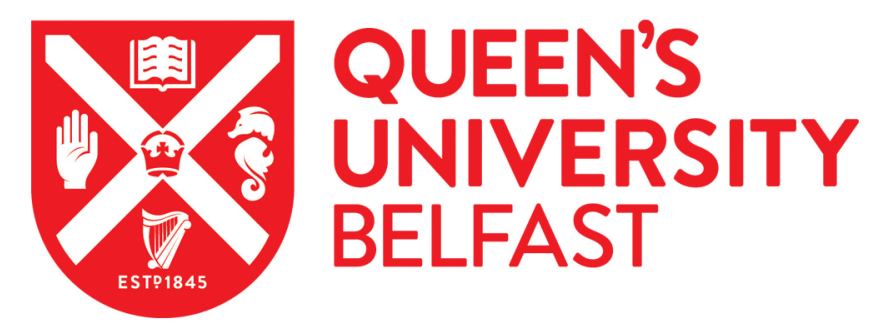

\title{
Applying species distribution modelling to a data poor, pelagic fish complex: the ocean sunfishes
}

Phillips, N. D., Reid, N., Thys, T., Harrod, C., Payne, N. L., Morgan, C. A., White, H. J., Porter, S., \& Houghton, J. D. R. (2017). Applying species distribution modelling to a data poor, pelagic fish complex: the ocean sunfishes. Journal of Biogeography. https://doi.org/10.1111/jbi.13033

Published in:

Journal of Biogeography

Document Version:

Peer reviewed version

Queen's University Belfast - Research Portal:

Link to publication record in Queen's University Belfast Research Portal

Publisher rights

(c) 2017 John Wiley \& Sons Ltd. This work is made available online in accordance with the publisher's policies. Please refer to any applicable terms of use of the publisher.

\section{General rights}

Copyright for the publications made accessible via the Queen's University Belfast Research Portal is retained by the author(s) and / or other copyright owners and it is a condition of accessing these publications that users recognise and abide by the legal requirements associated with these rights.

Take down policy

The Research Portal is Queen's institutional repository that provides access to Queen's research output. Every effort has been made to ensure that content in the Research Portal does not infringe any person's rights, or applicable UK laws. If you discover content in the Research Portal that you believe breaches copyright or violates any law, please contact openaccess@qub.ac.uk. 


\section{Original Article}

Applying Species Distribution Modelling to a Data Poor, Pelagic Fish Complex: The Ocean Sunfishes S. Porter ${ }^{1}$, J.D.R. Houghton ${ }^{1,2}$

${ }^{1}$ School of Biological Sciences, Queen's University Belfast MBC Building, 97 Lisburn Road, Belfast, BT9 7BL, U.K., ${ }^{2}$ Institute of Global Food Security, Queen's University Belfast, 18-30 Malone Road, Belfast, BT9 5BN, U.K., ${ }^{3}$ California Academy of Science, 55 Music Concourse Drive, Golden Gate Park, San Francisco, CA, 94118 U.S.A., ${ }^{4}$ Instituto de Ciencias Naturales Alexander von Humboldt, Universidad de Antofagasta, Avenida Angamos 601, Antofagasta, Chile, ${ }^{5}$ University of Roehampton, Holybourne Avenue, London, SW15 4JD, Cooperative Institute for Marine Resources Studies, Oregon State University, 2030 S. Marine Science Center, Newport, OR 97365

*Author to whom correspondence should be addressed: Natasha Phillips, Queen's University Belfast, Medical Biology Centre, 97 Lisburn Road, Belfast, BT9 7AE, nphillips01@qub.ac.uk

Running head: Distribution and seasonal movements of ocean sunfishes

Keywords: Biogeography, Environmental Niche Models, Marine, Migration, Mola, sunfishes, Spatial Ecology 


\section{Abstract}

\section{Aim}

Conservation management of vulnerable species requires detailed knowledge of their spatial and temporal distribution patterns. Within this context species distribution modelling (SDM) can provide insights into the spatial ecology of rarely encountered species and is used here to explore the distribution pattern of ocean sunfishes (Mola mola and M. ramsayi). Both species are prone to high levels of bycatch and are classified respectively as Globally Vulnerable and Not Assessed by the IUCN; although their overall range and drivers of distribution remain poorly defined. Here, we constructed suitable habitat models for Mola spp. on a global scale and considered how these change seasonally to provide a much needed baseline for future management.

\section{Location}

Global.

\section{Methods}

Sighting records collected between 2000 and 2015 were used to build SDMs and provided the first global overview of sunfish seasonal distribution. Post-hoc analyses provided a quantitative assessment of seasonal changes in total range extent and latitudinal shifts in suitable habitat.

\section{Results}

Mola is a widely distributed genus; however, sightings exhibited significant spatial clustering most notably in coastal regions. SDMs suggested that Mola presence was strongly dependant on sea surface temperatures with highest probability of presence between 16 and $23^{\circ} \mathrm{C}$. The models identified significant variation in seasonal range extent with latitudinal shifts throughout the year; although large areas of suitable year-round habitat exist globally.

\section{Main conclusions}

We provided the first assessment of Mola distribution on a global scale, with evidence of a wide latitudinal range and significant clustering in localised 'hotspots' (notably between 40$50^{\circ} \mathrm{N}$ ). By assessing the results of SDMs alongside evidence from published satellite tagging studies, we suggest that the species within the genus Mola are highly mobile, acting as 
58 facultative seasonal migrants. By identifying key suitable habitat alongside potential 59 movement paths, this study provides a baseline that can be used in active conservation 60 management of the genus. 


\section{Introduction}

Conservation management efforts are dependent on a detailed understanding of the spatial distribution, biogeography and ecology of target species (Ferrier et al., 2002; Ricklefs, 2004; Rushton et al., 2004). For widespread or cryptic species this can pose significant challenges (Pearson et al., 2007; Rissler \& Apodaca, 2007). Species distribution models (SDMs, also known as ecological niche models, species-habitat models or predictive habitat models) assess the complex relationship between species occurrence records and environmental variation, even from limited datasets, and offers insight into habitat suitability both spatially and temporally (Elith \& Leathwick, 2009; Franklin, 2009). For little known oceanic species, such methods can provide a key starting point in understanding complex, wide-ranging distribution patterns and the mechanisms driving environmental tolerances (Elith et al., 2006).

One such family of oceanic taxa, the ocean sunfishes (or Molidae), are often described as rare, inactive drifters (Pope et al., 2010), however recent studies have revealed high density aggregations in coastal waters (e.g. Silvani et al., 1999; Pope et al., 2010; Syväranta et al., 2012), sustained long distance swimming of $\sim 48$ km per day (e.g. Cartamil \& Lowe, 2004; Nakamura et al., 2015; Thys et al., 2015) and repeated deep-diving to mesopelagic depths foraging for gelatinous prey (e.g. Cartamil \& Lowe, 2004; Nakamura et al., 2015). Such observations suggest that this is an active, highly motile taxon (Cartamil \& Lowe, 2004), with a broad trophic niche (e.g. Harrod et al., 2013; Nakamura \& Sato, 2014; Sousa et al., 2016a) and capable of travelling significant distances in a directed manner (see review, Pope et al., 2010). This suggests that Mola may have more complex ecology than previously thought (Syväranta et al., 2012), which poses broader implications for sustainable management. Such insight is important in light of current bycatch levels (Silvani et al., 1999; Cartamil \& Lowe, 2004; Pope et al., 2010), such as the reported capture of $>36000$ individuals per annum in 
86 Mediterranean drift gillnets (Petersen \& McDonell, 2007). Bycatch numbers coupled with 87 impacts of large-scale target fisheries, led to a recent IUCN Red List classification of Mola mola (L. 1758) as globally Vulnerable (Jing et al., 2010) and Data Deficient in Europe (see Table 1, Appendices). This Red Listing represents a tentative first step towards future management strategies and highlights areas of sunfish ecology that require further research, such as knowledge of their distribution and movements, which currently restricts management and conservation efforts.

Anecdotal evidence collated in a review by Pope et al. (2010) suggested that the Molidae (see Table 1. Appendices) have a pan-global distribution within temperate and tropical latitudes, although limited sighting records and inherent difficulties in species identification have led to problems in delineating species-specific ranges and seasonal movement patterns. Recent high-profile reports of ocean sunfishes at high latitudes, such as in Alaska (Dobbyn, 2015), have led many media outlets to speculate as to why these species are "suddenly" appearing so far north. However, without baseline data on the range extent of ocean sunfishes, it is difficult to know whether they have undergone recent expansion and, if so, what might be driving such changes. Although taken to be widespread (Cartamil \& Lowe, 2004), it is not yet known if ocean sunfishes adhere consistently to a migratory paradigm (whether obligate or facultative). Evidence from multiple studies, using satellite tags and accelerometer derived dead-reckoning (e.g. Sims et al., 2009; Dewar et al., 2010; Nakamura et al., 2015; Thys et al., 2015), suggests that Mola in temperate and subtropical regions may move to equatorial latitudes during autumn, for example, into UK and Japanese waters. However, other studies using satellite tracking (Hays et al., 2009) and dietary analysis (Harrod et al., 2013) suggest year-round, or at least long-term, residence in some regions, including in Mediterranean and South African waters. The results from these studies support 
suggestions of distinct, local populations with differing drivers of distribution; however, there is a paucity of evidence across wide spatio-temporal scales.

From a broader conservation perspective, the IUCN states that creating a "comprehensive, objective global approach for evaluating the conservation status of [all] species [is important in order to] inform and catalyse action for biodiversity conservation" (IUCN, 2016). In line with this statement, this study uses SDM to provide an initial assessment of the global distribution pattern of a vulnerable marine genus that is plagued with species-specific identification problems. We present basic life history information for the genus Mola and its seasonal range extent in relation to key predictive environmental parameters. This study provides an objective evidence base critical to providing a full IUCN Red Listing, upon which international management decisions can be founded.

\section{Materials and Methods}

\section{Data sources and manipulation}

Global sightings of Mola were collected from public databases, published papers and fisheries logs (see Appendix S1). A total of 14953 sightings, recorded between the years 1758 and 2015, were compiled before specific criteria were set for standardising the dataset. This study aimed to assess the distribution of the genus Mola which currently contains two species. Mola is easily distinguishable from other genera in the Molidae (Ranzania and Masturus, see Table 1. Appendices), due to its differing morphology, and therefore potential for confusion is limited. We accept that misidentification is possible, but by maintaining a conservative approach to data acquisition (i.e. by removing records not identified to genus), we have tried to mitigate this risk. Any incomplete records (missing location or date of observation) were removed. All sighting locations were converted to decimal degrees, and mapped using ARCGIS 10.3.1 (ESRI, California, USA) and all locations that erroneously fell 
on land were removed. Although the sightings dataset extended over 257 years, $79 \%$ of sightings occurred between 2000 and 2015. Therefore only this subset of 5419 sightings was retained for further analysis. These sightings were divided into each quarter of the year (JanMar, Apr-May, Jun-Aug and Sep-Dec) and matched with recent climate data available through online data sharing platforms.

\section{Environmental parameters}

Climate data with near global oceanic coverage described surface oceanography at a resolution of one decimal degree delineated as a cellular matrix. The most recently collected dynamic parameters were selected and of these, sea surface temperature, nitrate, oxygen and chlorophyll concentration were averaged over three month periods suited to generating seasonal summaries (Jan-Mar, Apr-May, Jun-Aug and Sep-Dec). The datasets included sea surface temperature averaged from 2005 to 2012 (NOAA, 2015), nitrate and oxygen concentrations averaged from 1955 to 2012 (NOAA, 2015) and chlorophyll concentration averaged from 2002 to 2012 (NASA, 2012). Despite the extensive coverage provided by satellite data, the limitations of this dataset must be acknowledged; such as the lower quality data from nearshore or frequently clouded environments (Smith et al., 2013). Of all the parameters included, bathymetry was the only static variable recorded from a 2002-2003 global survey (NASA, 2003). If climatic data were missing from the decimal degree cell in which a sighting was recorded, it was removed from the analysis (leaving $n=4985$ sightings).

\section{Data validation}

Since all Mola data collected were 'presence only' sightings, we implemented a bias file as a proxy of survey effort to indicate the likelihood of being encountered and recorded, as 
presence-absence models perform better than presence only models (Elith et al., 2006). Since true absence data were not available, we followed established methods to construct a 'bias file' (e.g. Phillips et al., 2009; Aguirre-Gutierrez et al., 2013: Pokharel et al., 2016). This process requires the identification of a suitable proxy species (termed a target group) for which further presence data were available (e.g. Ponder et al., 2001: Anderson, 2003). We chose to use the leatherback turtle, Dermochelys coriacea (Vandelli, 1761) as it is suggested to inhabit similar environments to ocean sunfishes (Hays et al., 2009). Moreover, the species is an active predator of gelatinous zooplankton and conforms to the seasonal migration paradigm suggested for sunfishes (see Pope review, 2009), while being subject to similar sea surface and coastal observation biases (Houghton et al., 2006; Hays et al., 2009). Leatherback turtle sightings data were downloaded from the Global Biodiversity Information Facility sightings database (GBIF, 2015). The use of target group data has been reported to provide a considerable improvement in model performance, providing more realistic data than taking pseudo-absences from sites that have not been sampled at all (e.g. Phillips, 2009; Mateo et al., 2010; Aguirre-Gutierrez et al., 2013). The rationale here is that leatherback sightings provided a proxy for recorder presence with the inference that ocean sunfish sightings would have been recorded concurrently if present. Correspondingly, these locations were used to generate ocean sunfish pseudo-absence data $(n=434)$ to train SDMs.

\section{Statistical Analysis \& SDMs}

The distribution of Mola was mapped globally and a minimum convex hull containing all sightings created to satisfy the IUCN Red List range map requirements. Owing to the cryptic speciation within Mola, such range mapping was constrained to genus level.

A cluster analysis of sightings was performed using a Clark-Evans nearest neighbour test (Clark \& Evans, 1954) using the R x64 3.2.2 (R Development Core Team, 2008) package 
'spatstat' (Baddeley et al., 2015). The degree of grouping was determined using a correction cumulative distribution function and a Monte Carlo test to provide a probability value.

Climatic data were tested for collinearity using Pearson's correlation, before SDMs were produced using the R package 'Biomod2' (Thuiller et al., 2015). Seven SDM types were assessed including: surface range envelopes $(\mathrm{SRE}$, quant $=0.025)$, classification tree analysis $(\mathrm{CTA}, \mathrm{CV} \cdot$ tree $=50)$, random forest $(\mathrm{RF})$, multiple adaptive regression splines $(\mathrm{MARS})$, flexible discriminant analysis (FDA), generalised linear models (GLM, type = simple) and generalised additive models (GAM, spline $=3$ ). The models were designed with an 80:20 data split for training and testing and run with a 5000 fold cross validation. All models used in Biomod2 were run using the default settings recommended by Thuiller et al. (2010). Using this model design, the seasonal distribution of Mola was predicted using matched sightings and environmental data from each quarter of the year.

Model evaluation statistics were calculated including the Kappa value $(k)$, true skill statistic (TSS) and area under the curve (AUC) of the receiver operating characteristic (ROC). These evaluation metrics are frequently used to evaluate SDM performance, although AUC values have recently been criticised for overestimating performance by including large areas of absence data (Lobo et al. 2008; Leach et al. 2015). Popular alternatives also have limitations, such as TSS which is calculated from sensitivity and specificity, which themselves can contain misleading commission errors (Leach et al. 2015). The Kappa value provides a more objective measure of prediction accuracy, although this can also produce commission errors (Leach et al. 2015), but it provides accepted thresholds used in model evaluation. Here, we present each evaluation metric for all models however, the final evaluation of model accuracy used Kappa.

The optimal SDM was selected from those with a Kappa $>0.4$ (see Table 2), as this threshold has been widely used in a range of published work (Landis et al., 1977; Altman, 
1990; Allouche et al., 2006; Leach et al. 2015). The random forest model was the single best approximating model selected for further analysis and re-run with $100 \%$ of the sightings data to predict the seasonal probability of Mola presence globally.

To assess the seasonal range extent of Mola, the proportion of cells predicted with a probability of presence $>0.7$ was calculated and tested with a 4-sample test for equality of proportions without continuity correction. As the distribution data were strongly skewed, non-parametric tests were used. Due to uneven sampling, data were divided into Northern and Southern Hemispheres and the predicted range extent of Mola examined by plotting box and whisker diagrams of the latitudinal range divided by season and compared statistically using a Kruskal-Wallis test. To assess if individual Mola move seasonally in accordance with the model predictions, the latitude of all sightings were plotted against the Julian day of the year on which they were recorded and fitted with a locally weighted scatterplot smoothing curve (LOESS).

\section{Results}

Mola observations were distributed globally (Fig. 1a and b) but with significant clustering (z $=0.335, \mathrm{p}<0.05)$, with aggregations in North American and European coastal waters predominately between $20-60^{\circ} \mathrm{N}$, and peaking at $50^{\circ} \mathrm{N}$ (Fig. 2).

Nitrate and oxygen concentrations were significantly correlated $(r=0.88, p<0.001)$, and since nitrate is used here as a proxy for productivity, it was removed to avoid leverage in statistical models. The random forest model had the highest model evaluation statistic values (mean values of 5 model runs: Kappa $=0.63$, TSS: 0.72 , ROC: 0.93 ) and were thus chosen as the optimal SDM technique.

Random forest LOESS curves suggested Mola presence was associated with shallow, temperate $\left(7-23^{\circ} \mathrm{C}\right)$, relatively low productivity (chlorophyll $\left.<125 \mathrm{mg} / \mathrm{m}^{3}\right)$, oxygen rich $(>$ 
4ml/L) coastal waters (Fig. 3a-d). However, cells predicted to have a probability of presence $>0.7$ were widespread in all seasons resulting in a pan-global distribution in surface waters (Fig. 4a and b); but with lowest occurrence in polar and equatorial waters. The extent of suitable habitat (defined as the percentage suitable ocean surface) varied significantly between seasons $\left(\chi_{\mathrm{df}=3}^{2}=591.2, \mathrm{p}<0.001\right.$; Table 3$)$. The latitudinal range of Mola also varied significantly in both Northern (tested individually) across all seasons $\left(\chi_{\mathrm{df}=3}^{2}=1690.5\right.$, tabulated $\left.\chi^{2} \mathrm{df}=3=8.81 \mathrm{e}^{-11}, \mathrm{p}<0.001\right)$ and Southern Hemispheres $\left(\chi_{\mathrm{df}=3}^{2}=3121.2\right.$, tabulated $\left.\chi_{\mathrm{df}=3}^{2}=8.81 \mathrm{e}^{-11}, \mathrm{p}<0.001\right)$. Seasonal differences in latitudinal range reflected movement patterns, with the latitude of individual sightings varying temporally in both the Northern and Southern Hemispheres with animals shifting to more northerly latitudes in both hemispheres between April and October (Figs. 5a and b).

\section{Discussion}

This study used detailed records from public sightings databases, alongside fisheries surveys and museum archives which provided global coverage of a Data Deficient genus (IUCN, 2016). Although public sightings are widely used in broad-scale ecological studies, such data come with caveats, such as potential misidentification of cryptic species, incorrect data entry or regions of limited data availability. Despite such restrictions, such citizen science initiatives offer extensive coverage well beyond the budget and feasibility of most research projects. One of the best known examples, the North American Christmas Bird Count, has been running for over 100 years, with millions of person hours contributed to survey effort (Bibby, 2003; Audubon, 2008). With careful interpretation and strict data processing, substantial quantities of data can be collated over wide spatial and temporal scales, to the same quality as those collected by experts (Danielsen et al., 2014). 
When applying SDM to sightings data, we must be aware of the limitations of the dataset in question, choose ecologically relevant variables (Mac Nally, 2000) and use appropriate methods (Elith \& Leathwick, 2009). However, despite potential pitfalls and limitations, SDM have become important tools for predicting species distribution patterns and subsequent conservation management (Kremen et al., 2007; Wiens \& Graham, 2005; Evans et al., 2015). In this study, SDM enabled us to delineate the range extent of ocean sunfishes, quantify distinct local clustering and describe seasonal changes in range extent accompanied with intra-annual movement patterns consistent with being a facultative seasonal migrant.

\section{Distribution patterns}

To date, there are two recognised species within Mola: Mola mola (L. 1758) and Mola ramsayi (Giglioli, 1883). Alongside these two species, recent papers have reported differences between the Atlantic and Pacific M. mola populations based on genetic and morphological studies (e.g. Bass et al., 2005; Yoshita et al., 2009; Gaither et al., 2016). Despite these discoveries, a formal classification of cryptic species is yet to be published, and the species taxonomy of Mola remains in flux (see review by Pope, 2009). In light of the current pressures faced by the ocean sunfishes, this study provides baseline information on Mola spatial ecology, which can be further refined to species-specific level as discrepancies over speciation resolve themselves over time.

Our study revealed that the genus Mola has a wide habitat range (see Fig. 1b) with confirmed sightings records extending $128^{\circ}$ of latitude from approximately $70^{\circ} \mathrm{N}$ near Altenfjord, Norway to $-58^{\circ} \mathrm{S}$ in the Beagle Canal, Chile (sightings contributed by Lukas Kubicek, pers. comm.). When compared to the latitudinal range extents of $>10000$ other marine species (Strona et al., 2012), this range would appear in the top 15 range extents (maximum reported range $150^{\circ}$ latitude). However, within this range, our analysis suggests that Mola frequently 
aggregate and cluster in specific regions rather than being distributed randomly. Such clustering may be partly an artefact of sighting bias in coastal regions and known hotspots, particularly in North American and Europe. Nonetheless, the findings presented here align well with anecdotal evidence that Mola occur in patchily distributed, high density aggregations, particularly in coastal waters (e.g. Silvani et al., 1999; Sims \& Southall, 2002; Houghton et al., 2006).

Several regions globally have already been identified as hosting annual aggregations of Mola mola, suggested to be shoals of juveniles $(<1 \mathrm{~m})$; for example in Camogli, Italy (Syväranta et al., 2012) and California, USA (Cartamil \& Lowe, 2004; Thys et al., 2015), whilst our analysis may help predict other areas with high density populations. We are aware that limited data availability such as sparse information from equatorial regions, may have a partial effect on our habitat suitability predictions, but this is likely reduced by our implementation of a bias file. To the best of our knowledge, we have defined the full range extent of Mola (Fig. 1b), however, as sightings were likely subject to significant observer bias. Indeed, the predicted presence from SDMs (Fig. 4b) may be of greater use to characterise the actual range extent Mola populations whilst predicted probability values are likely correlated with density.

\section{Environmental drivers of Mola distribution}

The Random Forest model provided the most reliable approximation of Mola distribution. Sea surface temperature and an indicator of regional productivity (chlorophyll $a$ concentration) have been proposed as primary drivers of Mola movements (e.g. Thys et al., 2015; Sims et al., 2009). Mola habitat suitability increased gradually with chlorophyll $a$ concentration until reaching a threshold of approximately $140 \mathrm{mg} \mathrm{m}^{-3}$ with habitat suitability declining rapidly at higher concentrations. Many studies comment on Mola range limitation 
in terms of minimum temperatures, and indeed we found sightings of Mola to be absent from waters below $7^{\circ} \mathrm{C}$. However, our data suggested that Mola have a similarly-defined upper thermal threshold, of approximately $23^{\circ} \mathrm{C}$, beyond which habitat suitability declined rapidly. In the Atlantic, M. mola were found to spend $\sim 99 \%$ of their time in water temperatures between $10-19^{\circ} \mathrm{C}$ over a three month period (Sims et al., 2009), with a similar thermal preference of $16-17^{\circ} \mathrm{C}$ suggested from Pacific studies (Nakamura et al., 2015). The suggested thermal preference of approximately $16^{\circ} \mathrm{C}$ is further supported by our results, with habitat suitability peaking at this value. Interestingly, the warmest ambient water conditions recorded by external data loggers on free swimming M. mola, was $22^{\circ} \mathrm{C}$ (Nakamura et al., 2015) with internal body temperatures ranging from $12-21^{\circ} \mathrm{C}$; considerably narrower than external ambient water temperatures experienced by the fish $\left(3-22^{\circ} \mathrm{C}\right)$. More recently, a study on spatial occupancy of tagged M. mola in the North East Atlantic suggested movements were strongly related to water temperature on regional scales with an "escape" from regional maxima of approx. $25^{\circ} \mathrm{C}$ (Sousa et al., 2016b). By combining such evidence alongside the modelled thermal response curves, we suggest that the genus Mola may have an upper thermal tolerance limit of approximately $23^{\circ} \mathrm{C}$, although occasional forays above this temperature may occur as demonstrated by the recording of an individual $M$. ramsayi at a maximum of $27.5^{\circ} \mathrm{C}$ (Thys et al., 2016). Further support for a thermal optimum of $16^{\circ} \mathrm{C}$ can be derived from a recent study comparing optimum temperatures for performance in the wild to maximum temperature experiences in fish species' ranges (Payne et al., 2016a). If a thermal optimum of $16^{\circ} \mathrm{C}$ is aligned with the expected response curve, then an upper thermal limit of $23^{\circ} \mathrm{C}$ would be expected from this genus (Payne et al., 2016b). The thermal limits identified in our study may, therefore, reflect a loss of performance beyond such limits, at a genus level, although further research will be required to confirm species specific responses. 
From post-hoc analysis of the range extent of Mola, it appears that presence is also associated with dissolved oxygen levels between 5 and $7 \mathrm{ml} / \mathrm{L}$. However, Thys et al. (2015) recently suggested that $M$. mola may be able to tolerate very low oxygen levels after observing individuals within ocean hypoxic zones at $60 \mathrm{~m}$. Following periods exposed to such conditions, it is likely that individuals may need to recover in well-oxygenated waters (Cartamil \& Lowe, 2004). To date, Mola mola and Mola ramsayi have been observed at maximum depths of 844 m (Potter \& Howell, 2011) and 483 m respectively (Phillips et al., 2015), suggesting that mesopelagic ranging of sunfishes is perhaps more common than previously thought (Phillips et al., 2015). However, although the Mola are capable of deep water ranging, large schools of small Mola spp. are often noted in coastal areas, possibly a reflection of their mixed diet at this life stage (e.g. Syväranta et al., 2012; Harrod et al., 2013; Nakamura \& Sato, 2014). The increased availability of benthic prey and discards in coastal waters may function as a driver of seasonal abundance in shallow water in the genus Mola (Harrod et al., 2013).

\section{Seasonal movements}

We identified large areas of suitable habitat available year-round for Mola, however, our results also suggested that the total suitable sea surface area and latitudinal position of varied significantly between seasons (see Fig. 5a). The predictive models (see Fig. 4) suggested that Mola thermal tolerance enables movement to higher latitudes in the Northern Hemisphere during the boreal spring to late summer, before retreating further south over the boreal autumn and winter months. Within the confines of this study, we were only able to model Mola presence in surface waters, however, these latitudinal movements may correspond to shifts in deep prey fields (Angel \& Pugh, 2000; Houghton et al., 2008). Our predicted seasonal movement of Mola supports evidence from tagging studies in the northwest and 
northeast Atlantic (e.g. Sims et al., 2009; Potter \& Howell, 2011; Sousa et al., 2016b), and northeast and northwest Pacific (e.g. Dewar et al., 2010; Thys et al., 2015), which identified seasonal movements of individuals driven by temperature and patchily distributed prey. However, despite a range of tagging studies providing data across the Northern Hemisphere, there are relatively few data available from the Southern Hemisphere on Mola movements. From the SDMs, we suggest that a similar pattern occurs in the Southern Hemisphere, where Mola are able to move to maximum southern latitudes during the austral spring to late summer and then retreat towards the equatorial regions during the austral winter (Fig. 5a and b). These broad scale movements reflect the migration patterns of many species, in accordance with the seasonal migratory paradigm, where warmer temperatures during summer months enable range extensions poleward, and which then contract as the seasons change; example species include bluefin tuna (Lutcavage et al., 1999), swordfish (Sedberry et al., 2001) and loggerhead turtles (Mansfield et al., 2009).

Our data suggest that although the average latitudinal position of Mola in surface waters varied over the seasons, much of the world's oceans remain suitable for Mola year-round, with a wide latitudinal range. It is apparent, therefore, that Mola cannot be classified as obligate migrants, owing to discrepancies in distribution between populations. Although the species within this study were all considered to be Mola mola, the more common of the two Mola species, inferred differences in movement strategy between populations may be due to misidentification and behavioural differences between $M$. mola and the lesser studied $M$. ramsayi (Pope et al., 2010). Mola ramsayi is morphologically very similar to M. mola (Bass et al., 2005), identified by 16 fin rays with 12 closely spaced ossicles, compared to the 12 fin rays and 8 broadly spaced ossicles and reduced band of denticles prior to the clavus of $M$. mola (Fraser-Brunner, 1951; Thys et al., 2013). Mola ramsayi was initially suggested to be the Southern Hemisphere species (Fraser-Brunner, 1951), however, individuals have since 
been identified in the Northern Hemisphere, including the Sea of Oman (Al Ghais, 1994), the Indian waters of Chennai (Mohan et al., 2006) and even co-occurring with M. mola (Bass et al., 2005). Further molecular genetic analyses are required to confirm species identification and to assess the movement ecology of these species (Pope et al., 2010).

Alongside the predicted distribution patterns modelled here, the average position of Mola raw sightings was consistent with the concept of seasonal migration. However, outliers to this pattern do exist, supported by evidence of prolonged residency (e.g. Hays et al., 2009; Harrod et al., 2013). Since this study only assessed Mola surface distribution, it does not provide information on depth distribution, however several studies suggest that Mola spends a significant proportion of time (up to $30 \%$ ) in surface waters less than $10 \mathrm{~m}$ deep (Potter \& Howell, 2010). Although sightings data alone will be insufficient to fully determine the seasonal distribution patterns of marine species (Southall et al., 2005), the frequent sightings of Mola in surface waters is related to their universal basking behaviour at the sea surface (Norman \& Fraser, 1938). We suggest that the surface prediction of Mola distribution will provide a useful measure of their global distribution.

Although the results of this study do not provide direct evidence of a reciprocal migration, they do support the suggestion that some populations move latitudinally as suitable conditions shift over the course of the year. Such long distance movements may be restricted to populations near the latitudinal limits of their distribution; however, further study is required to test this assertion. Taken together, these results suggest that the genus Mola contains populations subject to differing drivers of distribution and, therefore, we propose they may be classed as facultative seasonal migrants.

\section{Conclusions}


407 This study provides a first assessment of the spatio-temporal global biogeography of the 408 genus Mola. Taken together, our results suggest that the genus is globally distributed with 409 significant clustering in specific locations, influenced by sea surface temperatures ranging 410 from $\sim 7$ to $23^{\circ} \mathrm{C}$. Based on SDMs, we suggest that populations act as facultative seasonal 411 migrants with differing regional drivers of distribution. Although this study was able to 412 consider the potential influence of productivity (using the proxy variable of chlorophyll 413 concentration), future work may be able to assess smaller regions which have better data 414 availability. Further studies on the ontogenetic shifts in the diet of ocean sunfishes are also 415 required to integrate SDMs with international databases of putative prey items to explore the 416 life history significance of shallow water and offshore habitats in more detail.

418 Acknowledgements

419 The authors would like to acknowledge the generous contribution of all those who collected 420 and provided data for this study (for full list please see Appendix S1), particularly the 421 thousands of citizen scientists globally, without whom this work would not be possible. Many 422 thanks also to Lawrence Eagling for proof-reading the manuscript on several occasions. 423 N.D.P was funded by The Fisheries Society of the British Isles. 


\section{References}

425

426

427

428

429

430

431

432

433

434

435

436

437

438

439

440

441

442

443

444

445

446

447

448

Al-Ghais, S. (1994) A first record of Mola ramsayi (Osteichthyes: Molidae) for the United Arab Emirates. Tribulus, 4, 22.

Allouche, O., Tsoar, A., Kadmon, R. (2006) Assessing the accuracy of species distribution models: prevalence, kappa and the true skill statistic (TSS). Journal of Appliped Ecology, 43, $1223-1232$.

Altman, D.G. (1990) Practical statistics for medical research. Chapman and Hall, CRC Press London.

Anderson, R.P. (2003). Real vs. artefactual absences in species distributions: tests for Oryzomys albigularis (Rodentia: Muridae) in Venezuela. Journal of Biogeography, 30, $591-605$.

Angel M.V. \& Pugh P.R. (2000) Quantification of diel vertical migration by macroplankton and micronektonic taxa in the northeast Atlantic. Hydrobiologia, 440, 161-179.

Audubon (2008) Available at: http://www.audubon.org/Bird/cbc/.

Baddeley A., Rubak E., \& Turner R. (2015) Spatial Point Patterns: Methodology and Applications with R.

Bass A.L., Dewar H., Thys T., Streelman J.T., \& Karl S. a. (2005) Evolutionary divergence among lineages of the ocean sunfish family, Molidae (Tetraodontiformes). Marine Biology, 148, 405-414.

Bibby C.J. (2003) Fifty years of Bird Study : Capsule Field ornithology is alive and well, and in the future can contribute much more in Britain and elsewhere. Bird Study, 50, 194 210.

Cartamil D.P. \& Lowe C.G. (2004) Diel movement patterns of ocean sunfish Mola mola off southern California. Marine Ecology Progress Series, 266, 245-253.

Danielsen F., Pirhofer-Walz K., Adrian T.P., Kapijimpanga D.R.K., Burgess N.D., Jensen 

P.M., Bonney R., Funder M., Landa A., Levermann N., \& Madsen J. (2014) Linking public participation in scientific research to the indicators and needs of international environmental agreements. Conservation Letters, 7, 12-24.

Dobbyn P. (2015) Available at: http://www.ktuu.com/news/news/a-series-of-bizarre-fishsightings-reported-in-alaska/35733240.

Elith J., Graham C., Anderson R., Dudik M., Ferrier S., Guisan A., Hijmans R., Huettmann F., Leathwick J., Lehmann A., Li J., Lohmann L., Loiselle B., Manion G., Moritz C., Nakamura M., Nakazawa Y., Overton J., Peterson A., Phillips S., Richardson K., Scachetti-Pereira R., Schapire R., Soberon J., Williams S., Wisz M., \& Zimmermann N. (2006) Novel methods improve prediction of species' distributions from occurrence data. Ecography, 29, 129-151.

Elith J. \& Leathwick J.R. (2009) Species Distribution Models: Ecological Explanation and Prediction Across Space and Time. Annual Review of Ecology, Evolution, and Systematics, 40, 677-697.

Ferrier S., Biology S., \& Apr N. (2002) Mapping Spatial Pattern in Biodiversity for Regional Conservation Planning: Where to from Here? Mapping Spatial Pattern in Biodiversity for Regional Conservation Planning: Where to from Here ? 51, 331-363.

Franklin J. (2009) Mapping species distributions: spatial inference and prediction. Board Member of Landscape Ecology Journal of Vegetation Science, 336.

Fraser-Brunner A. (1951) The ocean sunfishes (Family Molidae). Bull Br Mus (Nat Hist) Zoo, 87-121.

GBIF (2015) Available at: http://doi.org/10.15468/dl.q3wkgk.

Harrod C., Syväranta J., Kubicek L., Cappanera V., \& Houghton J.D.R. (2013) Reply to Logan \& Dodge: "stable isotopes challenge the perception of ocean sunfish Mola mola as obligate jellyfish predators". Journal of fish biology, 82, 10-6. 
Hays G.C., Farquhar M.R., Luschi P., Teo S.L.H., \& Thys T.M. (2009) Vertical niche overlap by two ocean giants with similar diets: Ocean sunfish and leatherback turtles. Journal of Experimental Marine Biology and Ecology, 370, 134-143.

Houghton J.D.R., Cedras A., Myers A.E., Liebsch N., Metcalfe J.D., Mortimer J. a., \& Hays G.C. (2008) Measuring the state of consciousness in a free-living diving sea turtle. Journal of Experimental Marine Biology and Ecology, 356, 115-120.

Houghton J.D.R., Doyle T.K., Davenport J., \& Hays G.C. (2006) The ocean sunfish Mola mola: insights into distribution, abundance and behaviour in the Irish and Celtic Seas. Journal of the Marine Biological Association of the UK, 86, 1237.

IUCN (2016) Available at: http://www.iucnredlist.org/about/overview.

Jing, L., Zapfe, G., Shao, K.-T., Leis, J.L., Matsuura, K., Hardy, G., Liu, M., Robertson, R. \& Tyler J. (2010) Available at: http://www.iucnredlist.org/.

Nakamura I., Goto Y., \& Sato K. (2015) Ocean sunfish rewarm at the surface after deep excursions to forage for siphonophores. Journal of Animal Ecology, 84, 590-603.

Nakamura I. \& Sato K. (2014) Ontogenetic shift in foraging habit of ocean sunfish Mola mola from dietary and behavioral studies. Marine Biology, 161, 1263-1273.

NASA (2003) Available at: http://neo.sci.gsfc.nasa.gov/view.php?datasetId=GEBCO_BATHY.

NASA (2012) Available at: http://neo.sci.gsfc.nasa.gov/view.php?datasetId=MY1DMM_CHLORA.

NOAA (2015) Available at: http://www.nodc.noaa.gov/OC5/woa13/woa13data.html. Payne N.L., Smith J.A., van der Meulen D.E., Taylor M.D., Watanabe Y.Y., Takahashi A., Marzullo T.A., Gray C.A., Cadiou G., \& Suthers I.M. (2015) Temperature-dependence of fish performance in the wild: links with species biogeography and physiological thermal tolerance. Functional Ecology, . 
Pearson R.G., Raxworthy C.J., Nakamura M., \& Townsend Peterson A. (2007) Predicting species distributions from small numbers of occurrence records: A test case using cryptic geckos in Madagascar. Journal of Biogeography, 34, 102-117.

Petersen S. \& McDonell Z. (2007) A bycatch assessment of the Cape horse mackerel Trachurus trachurus capensis mid- water trawl fishery off South Africa. Birdlife/WWF Responsible Fisheries Programme Report 2002-2005, .

Phillips N.D., Harrod C., Gates A.R., Thys T.M., \& Houghton J.D.R. (2015) Seeking the sun in deep, dark places: Mesopelagic sightings of ocean sunfishes (Molidae). Journal of Fish Biology, 87, 1118-1126.

Pope E.C., Hays G.C., Thys T.M., Doyle T.K., Sims D.W., Queiroz N., Hobson V.J., Kubicek L., \& Houghton J.D.R. (2010) The biology and ecology of the ocean sunfish Mola mola: A review of current knowledge and future research perspectives. Reviews in Fish Biology and Fisheries, 20, 471-487.

Potter I.F. \& Howell W.H. (2011) Vertical movement and behavior of the ocean sunfish, Mola mola, in the northwest Atlantic. Journal of Experimental Marine Biology and Ecology, 396, 138-146.

R Development Core Team (2008) R Development Core Team. .

Ricklefs R.E. (2004) A comprehensive framework for global patterns in biodiversity. Ecology Letters, 7, 1-15.

Rissler L.J. \& Apodaca J.J. (2007) Adding more ecology into species delimitation: ecological niche models and phylogeography help define cryptic species in the black salamander (Aneides flavipunctatus). Systematic Biology, 56, 924-942.

Rushton S.P., Merod S.J.O.R., \& Kerby G. (2004) New paradigms for modelling species distributions? Journal of Applied Ecology, 41, 193-200.

Silvani L., Gazo M., \& Aguilar a. (1999) Spanish driftnet fishing and incidental catches in 
Sims D.W., Queiroz N., Doyle T.K., Houghton J.D.R., \& Hays G.C. (2009) Satellite tracking of the World's largest bony fish, the ocean sunfish (Mola mola L.) in the North East Atlantic. Journal of Experimental Marine Biology and Ecology, 370, 127-133.

Sims D.W. \& Southall E.J. (2002) Occurrence of ocean sun $\notin$ sh, Mola mola near fronts in the western English Channel. J. Mar. Biol. Ass. U.K, 82, 927-928.

Sousa L.L., Queiroz N., Mucientes G., Humphries N.E., \& Sims D.W. (2016) Environmental influence on the seasonal movements of satellite-tracked ocean sunfish Mola mola in the north-east Atlantic. Animal Biotelemetry, 4, 7.

Syväranta J., Harrod C., Kubicek L., Cappanera V., \& Houghton J.D.R. (2012) Stable isotopes challenge the perception of ocean sunfish Mola mola as obligate jellyfish predators. Journal of fish biology, 80, 225-31.

Thuiller A.W., Georges D., Engler R., Georges M.D., \& Thuiller C.W. (2015) Package "biomod2." .

Thys T.M., Ryan J.P., Dewar H., Perle C.R., Lyons K., O’Sullivan J., Farwell C., Howard M.J., Weng K.C., Lavaniegos B.E., Gaxiola-Castro G., Miranda Bojorquez L.E., Hazen E.L., \& Bograd S.J. (2015) Ecology of the Ocean Sunfish, Mola mola, in the southern California Current System. Journal of Experimental Marine Biology and Ecology, 471, $64-76$.

\section{Supporting information}

Appendix S1 Data sources table of global sunfish sightings

\section{Biosketch}

Natasha Phillips is a $\mathrm{PhD}$ researcher at the University of Belfast interested in the movement ecology, diet and energetics of ocean sunfishes (family Molidae). 
550 Editor and Handling Editor

551 Michelle Gaither and Şerban Procheş

552

553 Author contributions:

554 NDP, JDRH, TT, NR and CH conceived the ideas. TT and CM collected data. NDP and JH

555 led the writing. HJW, SP, NR, NP advised on analysis. NDP analysed the data. 
Tables

Table 1. IUCN Red List designation for ocean sunfishes on both global and European scales.

\begin{tabular}{llll}
\hline & & & IUCN Red Listing \\
\cline { 3 - 4 } Species & Common name & Global Scale & European Scale \\
\hline Mola mola (L. 1758) & Ocean sunfish & Vulnerable & Data Deficient \\
Mola ramsayi (Giglioli 1883) & Southern ocean sunfish & Not Assessed & Not Assessed \\
Masturus lanceolatus (Liénard 1840) & Sharptail sunfish & Least Concern & Not Assessed \\
Ranzania laevis (Pennant 1776) & Slender sunfish & Least Concern & Data Deficient \\
\hline
\end{tabular}


Table 2. Evaluation metrics Kappa, true skill statistic (TSS) and receiver operating characteristic (ROC) values for all species distribution models (mean value of five model runs \pm standard deviation). All models were performed in R, using package "Biomod2".

\begin{tabular}{lccc}
\hline SDM type & Kappa Value & TSS Value & ROC Value \\
\hline Surface Range Envelope & $0.14 \pm 0.01$ & $0.19 \pm 0.02$ & $0.60 \pm 0.01$ \\
Classification Tree Analysis & $0.42 \pm 0.03$ & $0.62 \pm 0.08$ & $0.83 \pm 0.05$ \\
Random Forest & $0.63 \pm 0.04$ & $0.72 \pm 0.04$ & $0.93 \pm 0.02$ \\
Multiple Adaptive Regression Splines & $0.36 \pm 0.04$ & $0.48 \pm 0.07$ & $0.81 \pm 0.04$ \\
Flexible Discriminant Analysis & $0.31 \pm 0.03$ & $0.41 \pm 0.04$ & $0.76 \pm 0.05$ \\
Generalised Linear Model & $0.25 \pm 0.01$ & $0.35 \pm 0.05$ & $0.71 \pm 0.03$ \\
Generalised Additive Model & $0.35 \pm 0.05$ & $0.45 \pm 0.07$ & $0.79 \pm 0.04$ \\
\hline
\end{tabular}


Table 3. Analysis of random forest species distribution models to consider the extent of suitable habitat for Mola using the seasonal predicted probability of genus presence in each grid cell.

\begin{tabular}{lcccc}
\hline & \multicolumn{4}{c}{ Season } \\
\cline { 2 - 5 } & Jan-Mar & Apr-Jun & Jul-Sep & Oct-Dec \\
\hline $\begin{array}{l}\text { Mean predicted probability of Mola presence } \\
\text { across all cells ( } \pm \text { standard deviation) }\end{array}$ & $0.49 \pm 0.50$ & $0.50 \pm 0.50$ & $0.44 \pm 0.50$ & $0.51 \pm 0.50$ \\
Total number of cells modelled & 41,009 & 41,369 & 41,579 & 41,369 \\
No. cells predicted as suitable ( $p>0.7)$ & 19,914 & 21,094 & 18,257 & 21,270 \\
\% of ocean surface predicted as suitable & 48.56 & 50.99 & 43.91 & 51.42 \\
\hline
\end{tabular}




\section{Figures}

Figure 1a. Global distribution of presence sightings of Mola (black) and pseudo-absences provided by sightings of leatherback turtles (grey) used in the species distribution model. b. Minimum convex hull range extent of Mola sightings data from 2000-2015. The origin of the base map is a spheroid WGS 1984 projection.
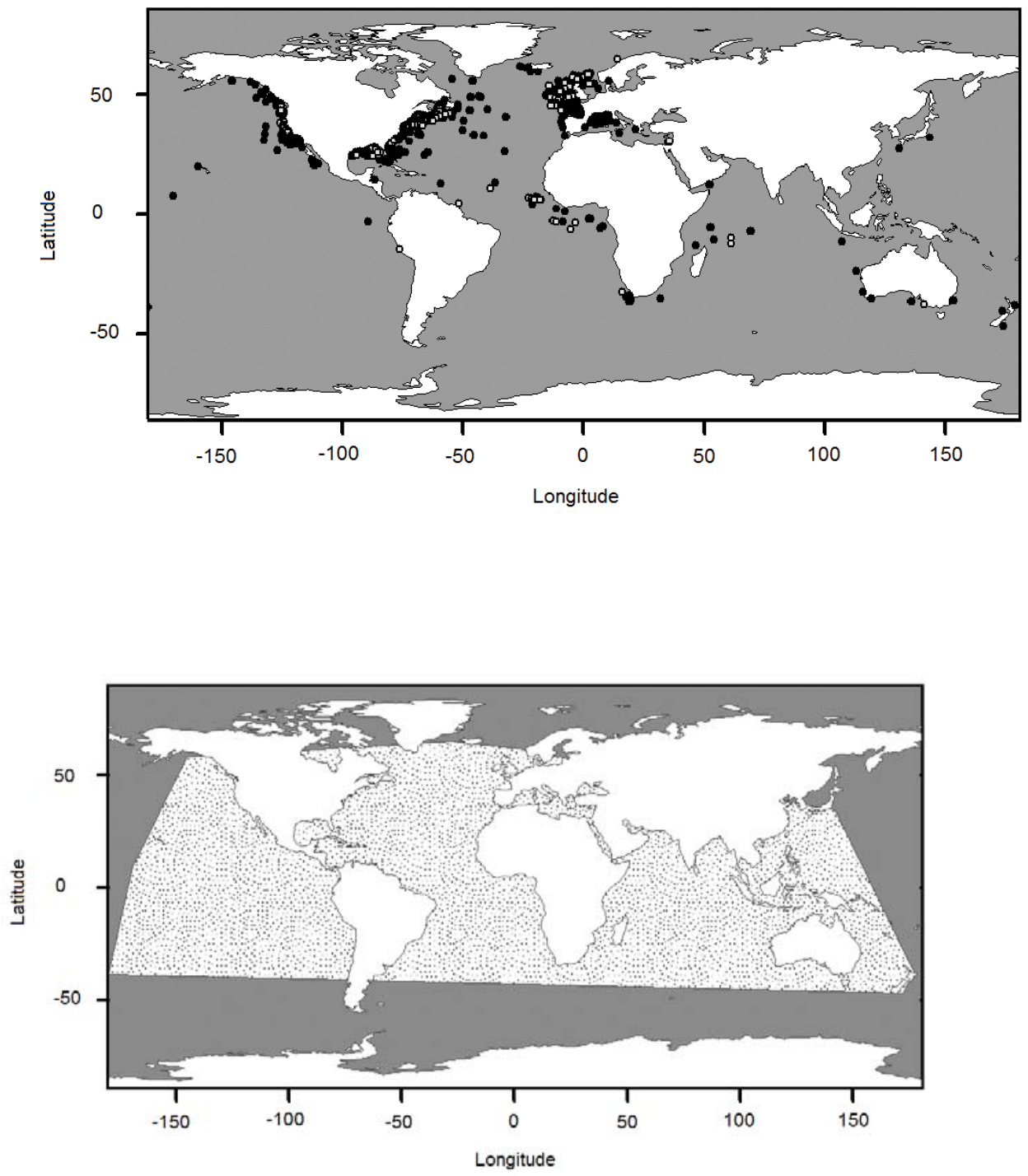
Figure 2. Frequency distribution of Mola sightings by latitude. The data showed a significant bias toward the Northern Hemisphere, particularly between $40-50^{\circ} \mathrm{N}$. The origin of the base map is a spheroid WGS 1984 projection.

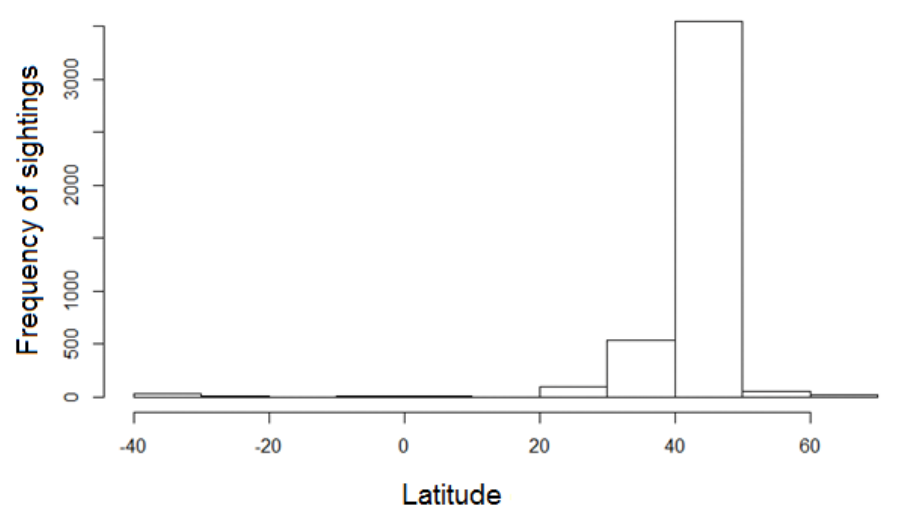

Figure 3. Species response curves for each climatic variable included in the final species distribution models (SDM) for Mola showing range suitability at the sea surface (0-1) against: a) bathymetry, b) sea surface temperature, c) chlorophyll concentration, and d) dissolved oxygen concentration.
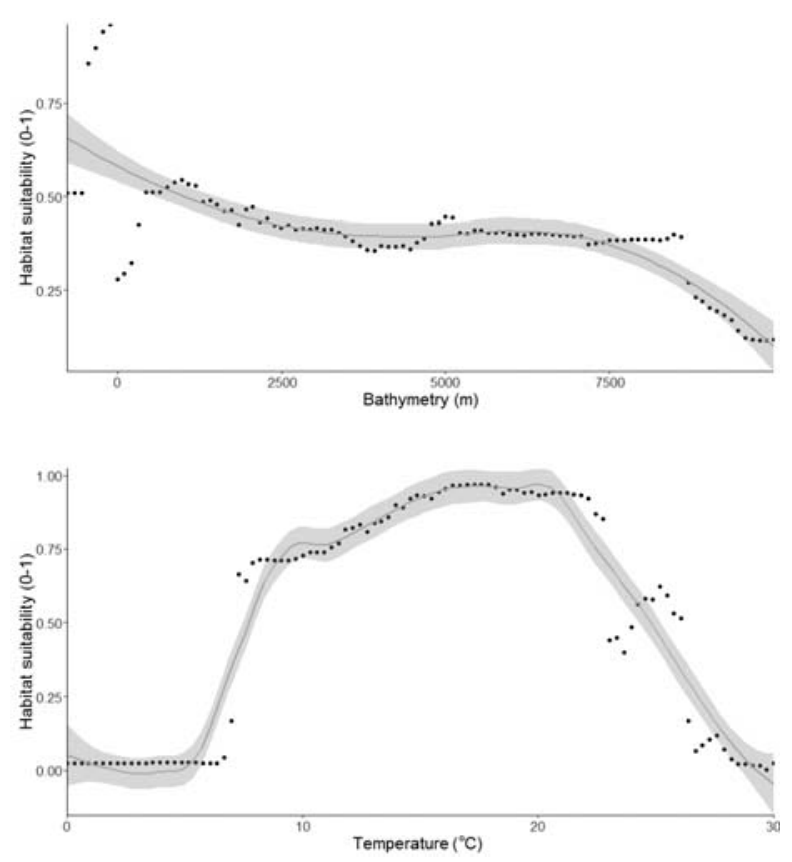

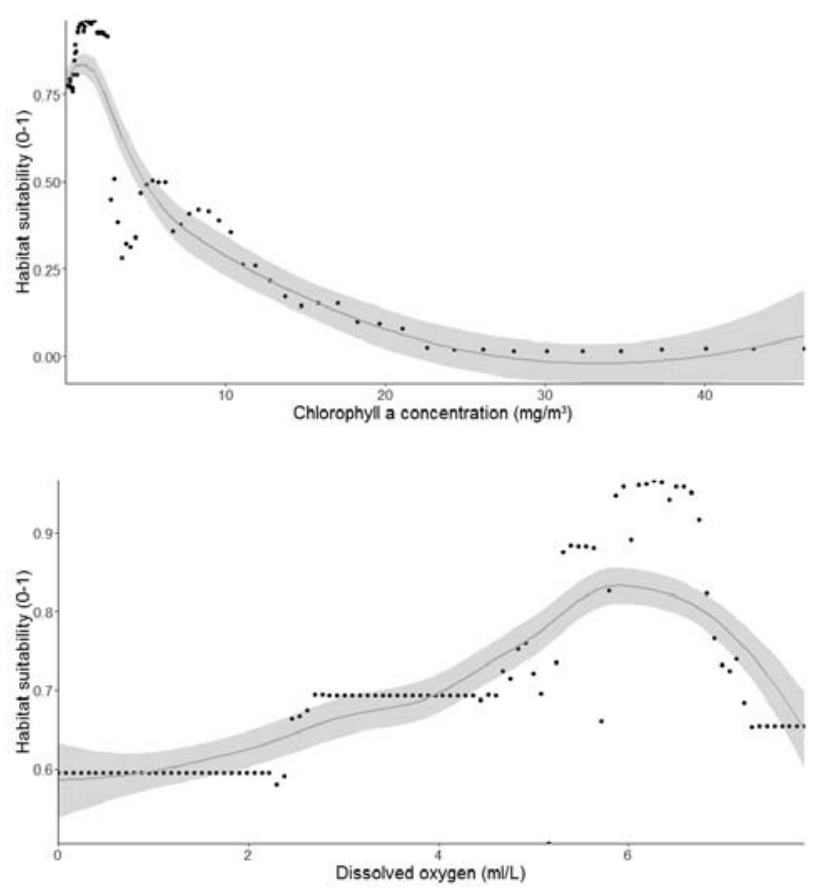

Figure 4a. Seasonal range suitability at the sea surface for Mola from species distribution model (SDM) outputs for i) January to March, ii) April to June, iii) July to September and iv) October to December. Probability of presence shaded from $0<0.1$ (white) to $0.9<1$ (black) at 0.1 intervals. b. predicted presence of Mola (probability $>0.7$ ). Predicted presence (black) and predicted absence (grey). The origin of the base maps is a spheroid WGS 1984 projection. 
ai)

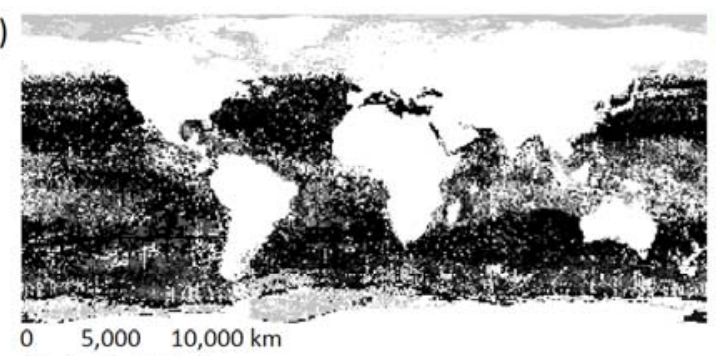

aii)

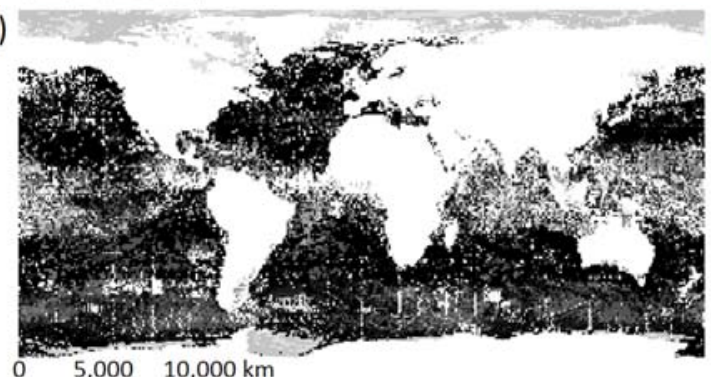

aiii)

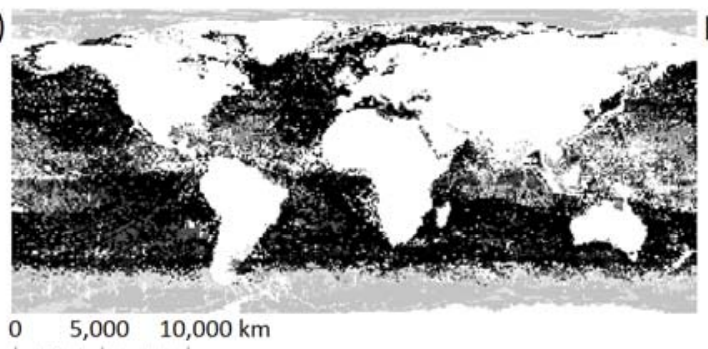

aiv)

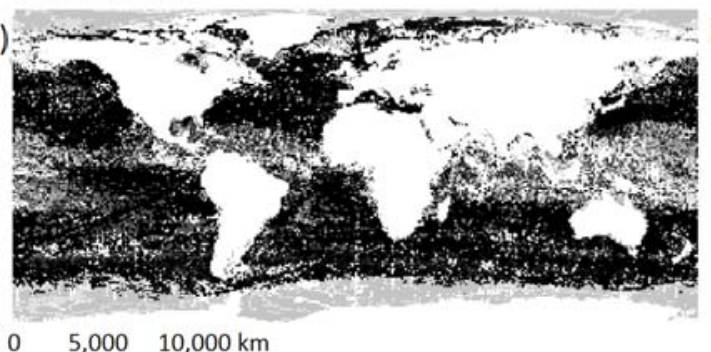

bi)

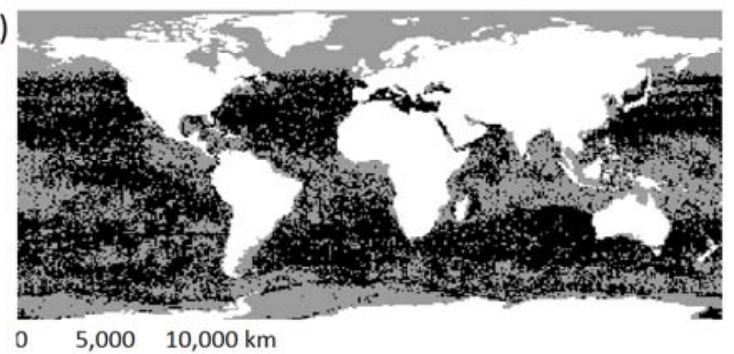

bii)

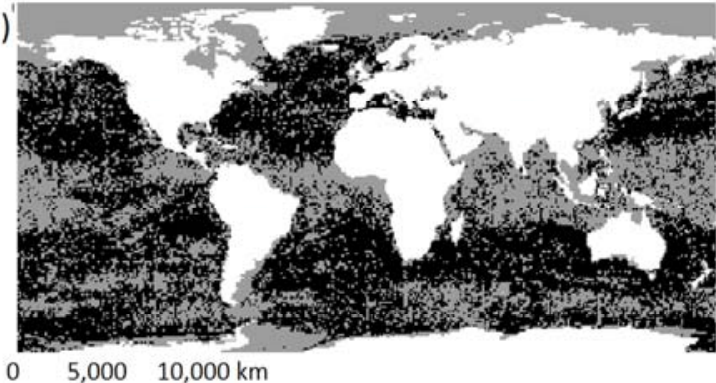

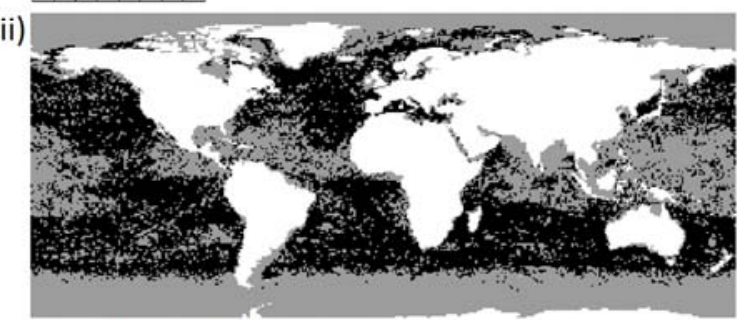

$0 \quad 5,000 \quad 10,000 \mathrm{~km}$

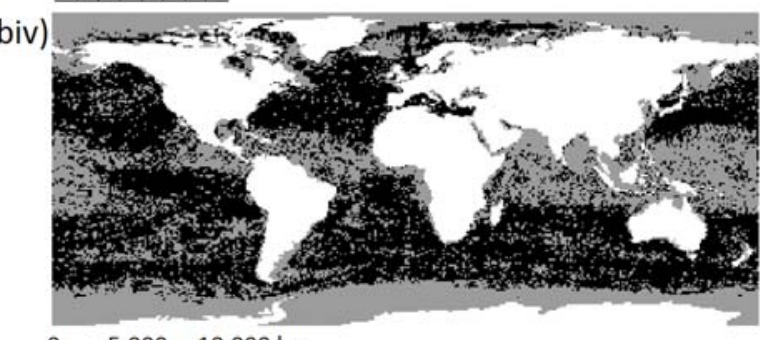

$5,000 \quad 10,000 \mathrm{~km}$

Figure 5a. Seasonal predicted latitudinal range of Mola in both hemispheres (outliers removed). b. Intra-annual variation in latitude of sightings data plotted by day of year with locally weighted scatterplot smoothing curve (LOESS) curve and 95\% confidence interval for both hemispheres.

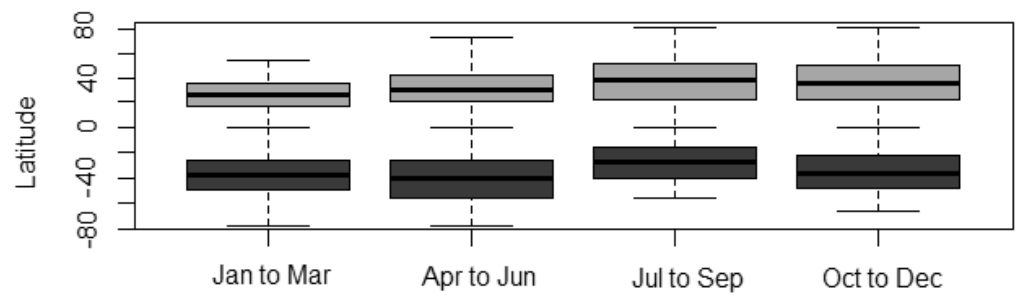




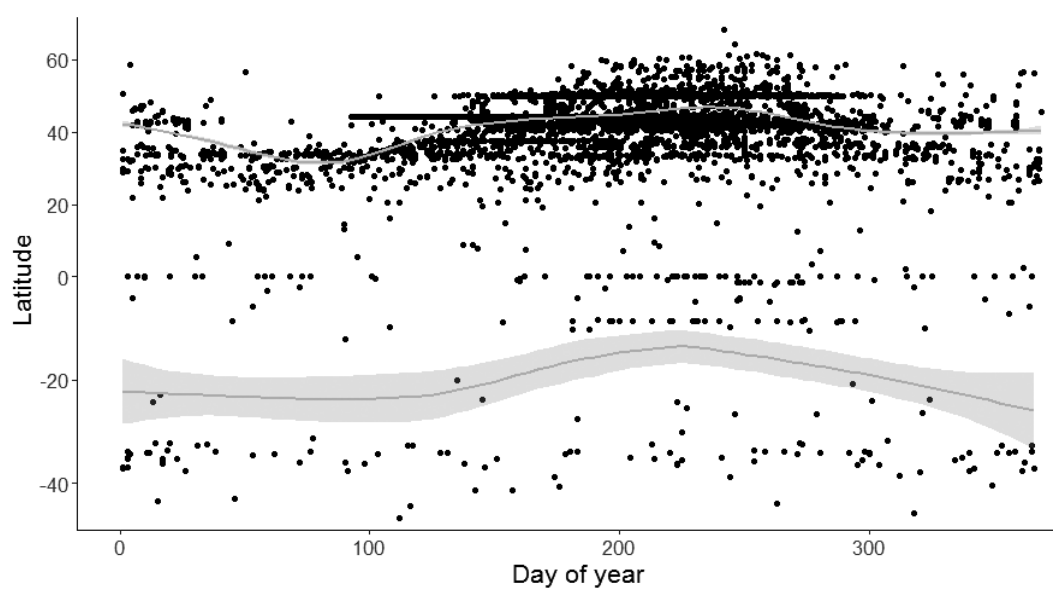

